\title{
Differences in the immune responses of mice and sheep to an aromatic-dependent mutant of Salmonella typhimurium
}

\author{
F. R. BRENNAN*, J. J. OLIVER and G. D. BAIRD \\ Moredun Research Institute, Gilmerton Road, Edinburgh
}

\begin{abstract}
Summary. A live mutant aroA Salmonella serotype Typhimurium ovine strain (S25/1) could be cultured from tissues of mice for up to 90 days after oral infection. Following vaccination, high levels of Salmonella-specific serum IgM, IgG and IgA were produced in addition to high levels of specific intestinal IgA. Moreover, there was also evidence of Salmonella-specific cellmediated immunity in vaccinated mice in the form of strong delayed-type hypersensitivity and the production of interferon-gamma (IFN- $\tau$ ) by spleen cells stimulated with Salmonella antigen. The aroA strain was also recovered from the mesenteric lymph nodes and most tissues examined from sheep vaccinated by the oral route. Salmonella-specific IgM was detected in the serum; however, specific IgG responses were very low and there was an absence of specific copro-antibody. Although strong Salmonella-specific lymphocyte proliferative responses were detected, they did not result in the production of IFN- $\tau$ and flow cytometric analysis revealed that the proliferating cells were predominantly B lymphocytes. Despite the absence of strong vaccine-specific immune responses in vaccinated sheep compared with those seen in mice, both mice and sheep were protected against challenge with virulent wild-type strain $\mathbf{S} 25 / 1$.
\end{abstract}

\section{Introduction}

Salmonellosis is a worldwide infectious disease of man and animals. As well as being a serious public health hazard, salmonellosis is of economic importance to the livestock industry, causing enteric infection, abortion and death in ruminant animals. This situation has been made worse by intensive husbandry practices and the stressful conditions associated with transit and shipping.

Salmonella serotype Typhimurium is one of the commonest causes of salmonellosis in man and animals in the UK, ${ }^{1,2}$ hence control of this particular serotype is a priority. Although Salmonella spp. are susceptible to antibiotics, this form of treatment either as a prophylactic or therapeutic measure is expensive and poses an undesirable risk of selection of antibioticresistant mutants. Thus, vaccination would offer the best means of control. Live vaccines have been shown to provide better protection against challenge with virulent Salmonella strains than killed vaccines. ${ }^{3-7}$ Such live vaccines also have the advantage that they provide longer-lasting immunity, can be administered via the oral route and do not cause the unpleasant sideeffects often associated with killed vaccines given by injection. ${ }^{8}$ Moreover, live vaccines do not require an

Received 20 Oct. 1993; revised version accepted 4 Jan. 1994

* Present address and address for correspondence: Department of Biochemistry, Rush-Presbyterian St Luke's Medical Center, 1653 West Congress Parkway, Chicago, IL 60612, USA. adjuvant to elicit strong cell-mediated immunity $(\mathrm{CMI}){ }^{9}$

AroA mutants of Salmonella have emerged as candidate live vaccine strains against salmonellosis. They are characterised by a non-reverting block in the common aromatic biosynthetic pathway as a result of a transposon-generated deletion within the aro $A$ gene. ${ }^{10}$ Such mutant strains have been shown to be avirulent and effective as vaccines in mice, ${ }^{10-12}$ poultry, ${ }^{13}$ calves $^{5,6,14}$ and sheep. ${ }^{7.15 .16}$ The aim of this study was to examine the immunogenicity of an aro $A$ mutant strain of Typhimurium and its ability to protect both mice and sheep from wild-type challenge. Experiments were designed to compare and characterise the immune responses to the vaccine strain in mice and sheep and to give an insight into the mechanisms that might mediate protection against virulent challenge.

\section{Materials and methods}

\section{Media}

Bacterial strains were cultured routinely in LuriaBertani (LB) Broth or on LB Agar (Difco). The complete media used for the isolation of salmonellae were Xylose Lactose Deoxycholate (XLD) agar (CM467B; Oxoid), Nutrient Broth No. 2 (code CM67; Oxoid) and Selenite Broth Base (code CM395; Oxoid) containing sodium biselenite (code L121; Oxoid) $4 \mathrm{~g} / \mathrm{L}$. 


\section{Bacterial strains}

The aro $A$ mutant Typhimurium strain used in this investigation was derived from a virulent ovine field strain $(\mathrm{S} 25 / 1)$ by transposon mutagenesis ${ }^{17}$ by the method of Hoiseth and Stocker. ${ }^{10}$ The aro $A$ and wildtype strains were cultured in LB broth in flasks with shaking at $37^{\circ} \mathrm{C}$ for $18 \mathrm{~h}$. After centrifugation at $7500 \mathrm{~g}$ for $10 \mathrm{~min}$, the pellet was washed three times in phosphate-buffered saline (PBS) and resuspended in PBS. The viable count $(\mathrm{cfu} / \mathrm{ml})$ was determined by the agar spread plate count technique. ${ }^{18}$ The killed preparation of the vaccine strain was produced by heating washed suspensions of the live $\mathrm{S} 25 / 1 \operatorname{aro} A\left(10^{9} \mathrm{cfu} / \mathrm{ml}\right)$ at $100^{\circ} \mathrm{C}$ for $30 \mathrm{~min}$. Fresh vaccine preparations were used for each experiment and were diluted appropriately in PBS before use.

\section{Experimental animals}

Conventional BALB/c mice (18-22 g) aged 6-8 weeks and conventional Blackface Suffolk Crossed sheep aged 9-12 months were produced at the Moredun Research Institute (MRI), Edinburgh. Mice (five/cage) were housed at room temperature and given food and water ad libitum. Sheep were housed in an open pen and fed on hay and nuts. Faecal swabs were taken from all the sheep before vaccination and inoculated into selenite broth before streaking on to XLD agar. Any animals excreting salmonellae were excluded from the studies.

\section{Experimental design of immunisation and challenge studies}

Mice. In the first experiment, mice were vaccinated with a single oral dose of $5 \times 10^{7} \mathrm{cfu}$ of S25/1aroA. From days 6 to 90 after vaccination, five mice were culled at regular intervals and the number of salmonellae $(\mathrm{cfu} / \mathrm{g})$ in the organs was determined (see below). The titres of specific antibody in the serum and intestine were measured by an enzyme-linked immunosorbent assay (ELISA) and the specific delayed-type hypersensitivity (DTH) was measured. In a second experiment, mice were inoculated with $1 \times 10^{8} \mathrm{cfu}$ of S25/1aroA and spleen cells were stimulated with Salmonella antigen in a lymphocyte transformation test (LTT) 35 days after vaccination. Other mice from this group were challenged with $5 \times 10^{7} \mathrm{cfu}$ of wildtype strain $S 25 / 1,40$ days after vaccination.

Sheep. In the first experiment, six sheep received a single oral dose of $5 \times 10^{11} \mathrm{cfu}$ of the $\mathrm{S} 25 / 1$ aro $A$ strain and the numbers of $\mathrm{cfu} / \mathrm{g}$ of organ were determined on days 6 and 12 after vaccination. In a second experiment, five sheep received $5 \times 10^{11} \mathrm{cfu}$ on days 0,2 , 4 and 24 and the levels of specific antibody in serum were determined by ELISA on days $0,4,8,11,14,18$, 21 and 30. Peripheral blood mononuclear cells (PBMC) were harvested from the same sheep on days $0,15,27$ and 35 and cultured with Salmonella antigen in an LTT. On day 40, these sheep were challenged with $5 \times 10^{11} \mathrm{cfu}$ of wild-type strain S25/1.

\section{Clinical parameters}

The demeanour of all the mice and sheep following vaccination and challenge was examined closely. Food intake was assessed every $24 \mathrm{~h}$. The rectal temperature of the sheep was measured daily and faecal samples taken on alternate days, from which the percentage dry weight was determined. The percentage packed cell volume of sheep blood samples, taken on days 2-12 after vaccination with S25/1aroA and on each day after challenge with wild-type strain $\mathrm{S} 25 / 1$, were determined to measure the extent of haemoconcentration.

\section{Blood collection}

Blood was collected from halothane-anaesthetised mice after cutting the hepatic vein. Blood was removed from the jugular veins of sheep and sera were stored at $-20^{\circ} \mathrm{C}$.

\section{Recovery of S25/laroA from specimens from mice and sheep}

Faecal pellets, liver, spleen and all Peyer's patches (free of intestinal wall) from each mouse were homogenised separately in $10 \mathrm{ml}$ of PBS in a "Stomacher 80" lab blender (Seward Medical, London) and $1 \mathrm{ml}$ of homogenate was plated on to XLD agar. After incubation of the plates at $37^{\circ} \mathrm{C}$ for $18 \mathrm{~h}$, viable counts were determined and expressed as the mean $\log _{10} \mathrm{cfu} / \mathrm{g}$ of the organ or faeces. Homogenates of tissue samples (c. $1 \mathrm{~g}$ in $10 \mathrm{ml}$ of PBS) from each sheep were also made and viable counts done as described above. The organs examined included heart, lung, bronchial lymph node, liver, hepatic lymph node, spleen, kidney, mesenteric lymph node, abomasum, ileum, caecum and colon. When bacteria could not be isolated after direct plating on to XLD agar, $1 \mathrm{ml}$ of homogenate was first enriched in $10 \mathrm{ml}$ of selenite broth and then plated on to XLD agar. Viable counts were expressed as $\log _{10} \mathrm{cfu} / \mathrm{g}$ of tissue for each sheep.

\section{Collection of intestinal Ig $A$}

Mice were dosed orally every $15 \mathrm{~min}$ for $1 \mathrm{~h}$ with $0.5 \mathrm{ml}$ of $48.5 \mathrm{~mm}$ polyethylene glycol (mol. wt 3350 ; Sigma); 20 min after the last dose, the mice were culled and the intestines and caeca were washed out twice with $5 \mathrm{ml}$ of ice-cold $50 \mathrm{~mm}$ EDTA containing soyabean trypsin inhibitor (Sigma) $0.1 \mathrm{mg} / \mathrm{ml}$. Samples were adjusted to $6 \mathrm{ml}$ with ice-cold PBS and centrifuged at $2500 \mathrm{~g}$ for $10 \mathrm{~min}$. Three $\mathrm{ml}$ of supernate were centrifuged at $69000 \mathrm{~g}$ at $4^{\circ} \mathrm{C}$ for 20 min after which $30 \mu \mathrm{l}$ of $0.2 \mathrm{M}$ phenylmethyl-sulphonylfluoride (PMSF) in ethanol $95 \% \mathrm{v} / \mathrm{v}$ and $30 \mu \mathrm{l}$ of sodium azide $2 \% \mathrm{w} / \mathrm{v}$ were added to $2 \mathrm{ml}$ of clarified supernate. Fetal calf serum (FCS; Sigma) was added at $3 \%$ and the samples were stored at $-70^{\circ} \mathrm{C}$. Faecal samples from sheep were homogenised in ice-cold EDTAsoyabean trypsin inhibitor; homogenates were centri- 
fuged at $25000 \mathrm{~g}$ for $10 \mathrm{~min}$ and sodium azide was added to the supernate to a final concentration of $0.01 \% \mathrm{w} / \mathrm{v}$. FCS $(100 \mu \mathrm{l} / \mathrm{ml})$ was added to the samples, which were then stored at $-70^{\circ} \mathrm{C}$.

\section{Extraction of lipopolysaccharide (LPS)}

The hot phenol-water extraction procedure ${ }^{19}$ was used for extracting LPS from a live 18-h culture of S25/1aroA . Highly purified LPS was obtained by preparative ultracentrifugation as described by Lindberg and Holme. ${ }^{20}$

\section{Immunological parameters}

S25/1aroA-specific antibody titres in the sera of individual mice or sheep were measured by an ELISA as described previously. ${ }^{21}$ Purified LPS from S25/ 1 aro $A$, at a concentration of $1 \mu \mathrm{g} / \mathrm{ml}$, was used to coat the ELISA plates (M129B; Dynatech). Anti-mouse IgM, IgG and IgA conjugated to alkaline phosphatase were obtained from Sigma. Horseradish peroxidaselabelled anti-sheep immunoglobulin conjugates were produced at MRI. The optical density (OD) of postvaccination serum was obtained by subtracting the OD of pre-vaccination serum from the same sheep or the OD of normal mouse serum.

\section{DTH reactions}

DTH skin reactions to intradermal injection of $50 \mu \mathrm{l}$ of a heat-killed preparation of $\mathrm{S} 25 / 1$ aroA (containing $2 \times 10^{8} \mathrm{cfu} / \mathrm{ml}$ ) were measured. Changes in flank double skin-fold (sheep) or hind footpad (mouse) thickness were assessed by measurement with dialgauge calipers (Kroeplin, Germany) before, and 24 and $48 \mathrm{~h}$ after injection of antigen.

\section{Lymphocyte transformation tests (LTTS)}

PBMC were obtained by passing heparinised whole blood over Lymphoprep (Nycomed, Oslo, Norway). ${ }^{22}$ Murine spleen cells were obtained by injecting $10 \mathrm{ml}$ of Hanks's Balanced Salts Solution (HBSS) containing heparin $1 \%$ under the splenic capsule. Both PBMC and spleen cells were washed twice in HBSS by centrifugation at $400 \mathrm{~g}$ for $5 \mathrm{~min}$, counted and resuspended in Iscove's Modification of Dulbecco's Medium (IMDM; Flow, Irvine) containing FCS (Northumbria Biological Limited) $5 \%$ and $10 \mathrm{~mm}$ penicillin/streptomycin. Cells $\left(2 \times 10^{5} / 200 \mu \mathrm{l}\right)$ were cultured with heat-killed S25/1aroA in the wells of flat-bottomed microtitration plates (Nunc/Gibco, Paisley) for $4-6$ days at $37^{\circ} \mathrm{C}$ in $\mathrm{CO}_{2} 5 \%$ in air. Cells were pulsed with tritiated thymidine (Amersham) $0.5 \mu \mathrm{Ci}$ for $18 \mathrm{~h}$, harvested with an automatic cell harvester (Flow) and the radioactivity incorporated into DNA was determined by counting on a liquid scintillation counter (Canberra Packard). The results for stimulated cells were expressed as net counts/min (cpm), calculated by subtracting the counts obtained with unstimulated cells.

\section{Interferon- $\tau(I F N-\tau)$ assay}

IFN- $\tau$ in salmonella-stimulated lymphocyte cultures was determined as described ${ }^{23,24}$ Briefly, mouse L929 cells or sheep ST-6 cells were grown in confluent monolayers and then incubated with graded dilutions of supernates for $24 \mathrm{~h}$. Cells were infected with Semliki Forest virus (SFV) and after 2 days the titres that inhibited the cytopathic effect (CPE) were determined. Titres were given as the highest dilution that reduced $\mathrm{CPE}$ by $50 \%$. To confirm that the activity was due to IFN- $\tau$, the test supernate were incubated for $2 \mathrm{~h}$ at $37^{\circ} \mathrm{C}$ in $\mathrm{CO}_{2} 5 \%$ with monoclonal anti-IFN- $\tau$ antibody before addition to the cells for assay.

\section{Analysis of the phenotype of ovine $P B M C$ responding to Salmonella antigen in vitro by flow cytometry}

Ovine PBMC were cultured with S25/1aroA as described above. After culture for 4-7 days, the cells were washed in Earle's Balanced Salts Solution (EBSS) supplemented with FCS (Sigma) $2 \%$ and sodium azide $0.5 \% \mathrm{w} / \mathrm{v}$, counted and $1 \times 10^{6}$ cells were resuspended in the appropriate monoclonal antibody (MAb). The MAbs used were mouse anti-sheep CD4, CD8, T-cell receptor gamma-delta $(\tau-\delta)$ and immunoglobulin light chain. Anti-Border Disease virus MAb was used as a negative control. After $1 \mathrm{~h}$ on ice, the cells were washed twice in EBSS at $400 \mathrm{~g}$, resuspended in $50 \mu \mathrm{l}$ of a 1 in 25 dilution of fluorescein-labelled rabbit anti-mouse IgG conjugate (Dako Ltd) and incubated on ice in the dark for $1 \mathrm{~h}$. After two more washes in EBSS, the cells were fixed in $400 \mu \mathrm{l}$ of paraformaldehyde $1 \%$ in EBSS and stored at $4^{\circ} \mathrm{C}$ in the dark until examined on a FACSCAN (BectonDickinson) with Lysis 1 software.

\section{Statistical analysis}

Student's unpaired $t$ test was used to calculate significant differences $(p<0.05)$ between control and experimental groups.

\section{Results}

\section{Clinical responses after vaccination with S25/1aroA}

No clinical symptoms developed in any of the mice or sheep following vaccination.

\section{The distribution of $S 25 / 1$ aroA in vivo after oral inoculation}

After oral inoculation of mice, salmonellae were isolated from all tissue and faecal samples examined from day 6 until day 54 when Peyer's patches were free from infection (fig. 1). The organism was recovered 
a

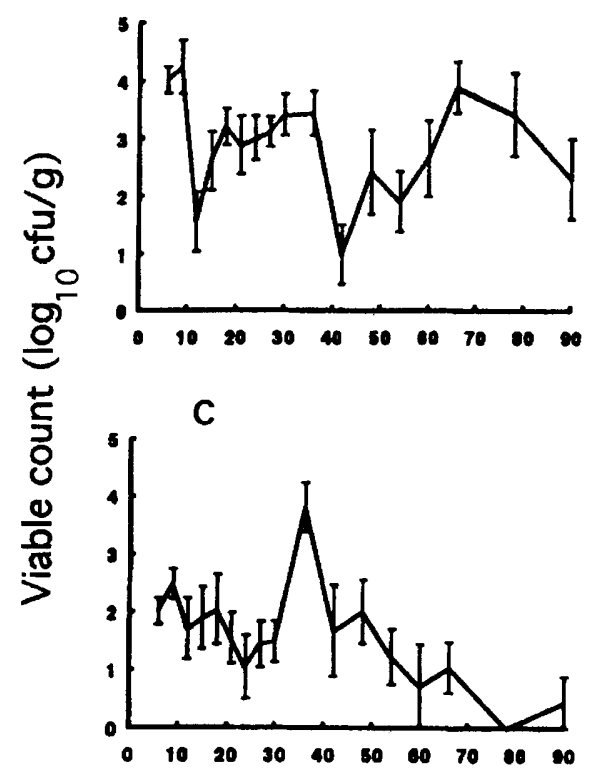

b

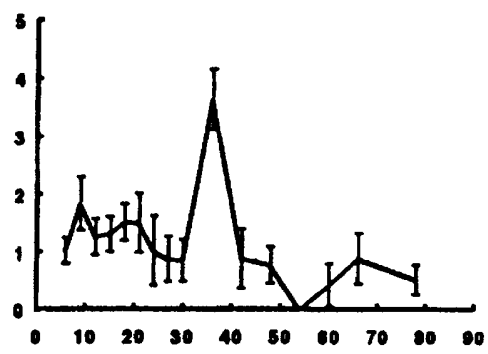

d

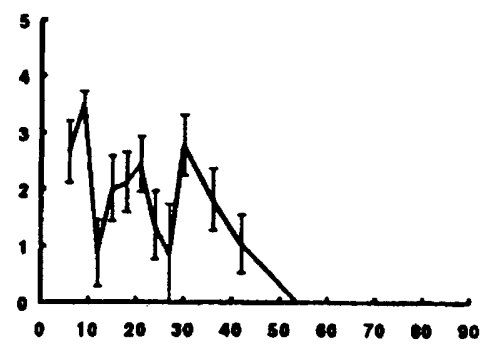

Days after infection

Fig. 1. Persistence of strain $\mathrm{S} 25 / 1$ aro $A$ in the faeces and tissues of mice after oral inoculation with $5 \times 10^{7} \mathrm{cfu}$. The mean cfu $/ \mathrm{g}$ was determined for (a) faeces, (b) liver, (c) spleen, (d) Peyer's patches in five mice. Levels are expressed as $\log _{10} \mathrm{cfu} / \mathrm{g}$.

a

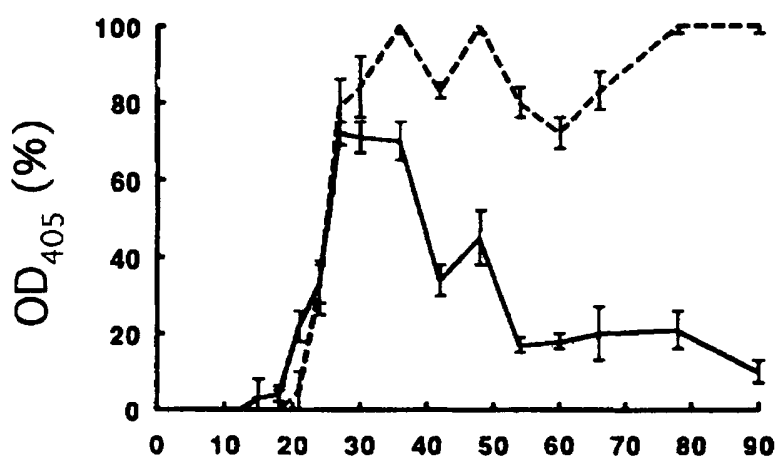

b

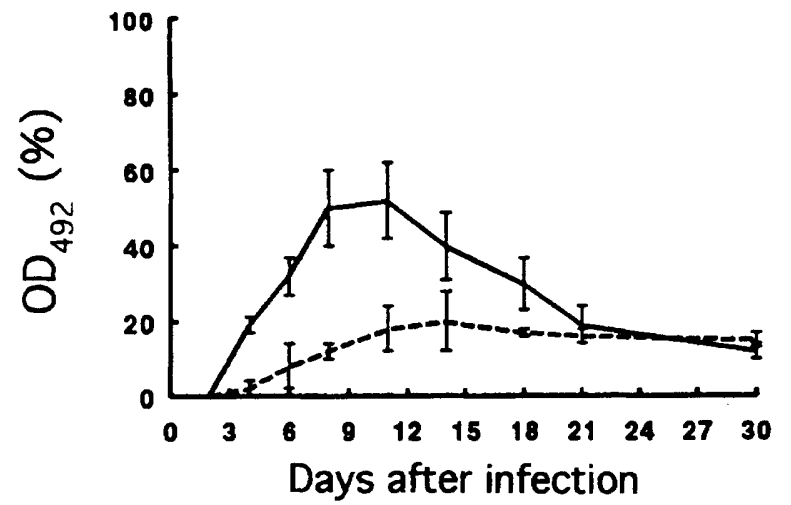

Fig. 2. Specific serum antibody in (a) mice and (b) sheep after oral vaccination with strain S25/1aroA. The sera were tested in an ELISÁA for Salmonella-specific IgM (-) and IgG (--). Mouse serum was diluted 1 in 200 for both IgM and IgG and sheep serum was diluted 1 in 200 and 1 in 40 for IgM and IgG, respectively. Each point represents the mean $\mathrm{OD}_{405}$ of five mice or the mean $\mathrm{OD}_{492}$ of five sheep. Mean OD values are expressed as a percentage where $100 \%$ represents OD 1.8 .

from the liver until day 78 and was still present in the spleen and being excreted in faeces at the termination of the experiment on day 90 .

In sheep, the mesenteric lymph nodes contained
Table.I. Recovery of strain S25/1aro $A$ from the organs of sheep after oral infection

\begin{tabular}{|c|c|c|c|c|c|c|}
\hline \multirow{3}{*}{ Tissue } & \multicolumn{6}{|c|}{ Viable count $(\mathrm{cfu} / \mathrm{g})$ in tissue from sheep* killed on } \\
\hline & \multicolumn{3}{|c|}{ Day 6} & \multicolumn{3}{|c|}{ Day 12} \\
\hline & 1 & 2 & 3 & 4 & 5 & 6 \\
\hline Heart & 2 & 180 & 10 & 400 & 457 & 40 \\
\hline Lung & 0 & 290 & 0 & 50 & $3 \times 10^{8}$ & 689 \\
\hline BLN & 8 & 60 & 0 & 0 & 5 & 0 \\
\hline Liver & 26 & $1 \times 10^{3}$ & 50 & 111 & 721 & 139 \\
\hline HLN & 28 & 12 & 15 & 0 & 801 & 23 \\
\hline Spleen & 0 & 28 & 7 & 10 & 283 & 4 \\
\hline Kidney & 0 & 440 & 6 & 13 & 636 & 700 \\
\hline MLN & 180 & $2 \times 10^{3}$ & $2 \times 10^{3}$ & $3 \times 10^{3}$ & 86 & 122 \\
\hline Ileum & + & 40 & $4 \times 10^{3}$ & 238 & 615 & $1 \times 10^{3}$ \\
\hline Caecum & + & + & + & 0 & 0 & 0 \\
\hline Colon & + & + & + & 0 & 0 & 0 \\
\hline
\end{tabular}

BLN, bronchial lymph node; HLN, hepatic lymph node; MLN, mesenteric lymph node; + , organism detected only after enrichment.

* Sheep were inoculated orally with three doses of $10^{11} \mathrm{cfu}$ of strain S25/laroA on days 0,2 and 4 and three sheep were culled on days 6 and 12 .

substantial numbers of the vaccine strain and varying levels of colonisation were present in the majority of other tissues taken from each sheep at both times tested (table I).

Serum antibody responses in mice and sheep after oral vaccination with S25/1aroA

Titres of serum IgM and IgG antibody to LPS of the vaccine strain were determined by ELISA and the results for both mice and sheep are shown in fig. 2 . In mice, IgM began to appear between days 18 and 21 and rose to high titres by day 28 before falling, although antibodies were still detectable on day 90 . 


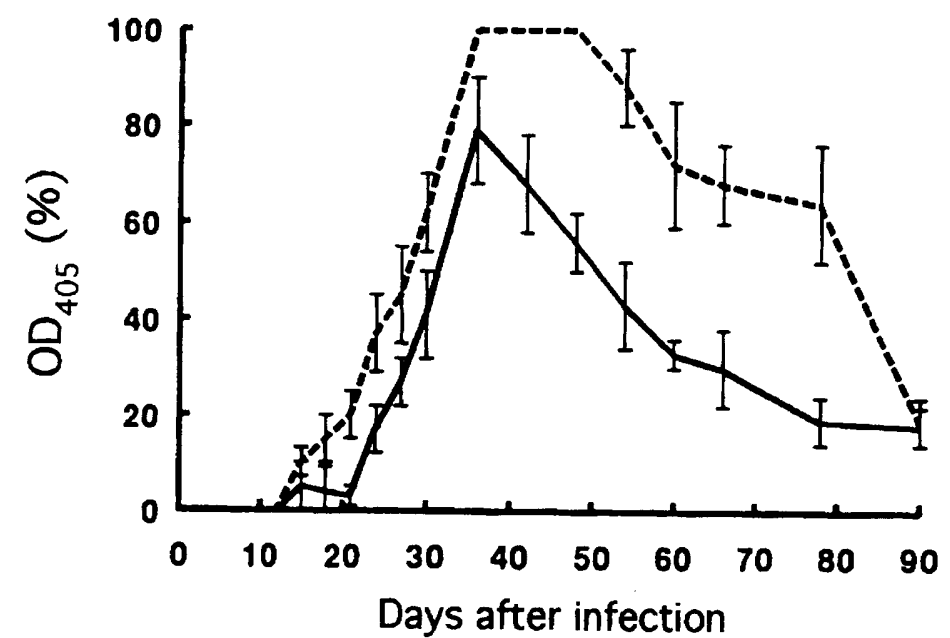

Fig. 3. Specific intestinal (-- ) and serum (-) IgA in mice inoculated orally with $5 \times 10^{7}$ cfu of strain $\mathrm{S} 25 / 1$ aro $A$. The sera and gut washes were tested in an ELISA for Salmonella-specific IgA. Each point represents the mean OD $_{405}$ of five mice at a 1 in 200 serum dilution or 1 in 4 lavage dilution.

IgG appeared on day 21 , reached high levels by day 28 and remained high until termination of the experiment.

In sheep, IgM appeared on day 5 and rose steadily until day 12 when titres started to fall. Titres of IgG were much lower than for IgM and appeared on days $8-12$, remaining relatively constant throughout the subsequent course of the studies.

Intestinal antibody responses in mice and sheep after oral vaccination with $S 25 /$ laroA

Titres of intestinal (gut) IgA in mice against LPS of the vaccine strain were determined by ELISA and are shown in fig. 3, where they are compared with the serum $\operatorname{IgA}$ titres. Intestinal $\operatorname{IgA}$ antibody appeared on days 14-18 with serum IgA appearing slightly later. The antibody profiles of intestinal and serum IgA were very similar; titres of both rose together and reached high levels on days 36 when they started to fall. High titres of intestinal $\operatorname{IgA}$ were sustained for longer than serum IgA; however, both were still detectable on day 90 .

In sheep, copro-antibody was not detected in any of the five sheep at any time, even after challenge with wild-type strain $\mathrm{S} 25 / 1$.

Specific DTH responses in mice and sheep after oral vaccination with $S 25 /$ laroA

Specific increases were detected as early as day 9 after vaccination in mice, remained constant until 6 weeks and then increased steadily until termination of the experiment (fig. 4). In some unvaccinated mice, no increase in the footpad thickness was detected and in others the response was negligible.

In sheep, large non-specific increases in skin-fold thickness were recorded in all sheep irrespective of whether they had been vaccinated, making the results impossible to interpret. As an alternative, the in-vitro responsiveness of the PBMC to Salmonella antigen was examined in an LTT.
Salmonella-specific lymphocyte proliferative responses of mice and sheep after vaccination with S25/1aroA

The proliferative responses of spleen cells to $\mathrm{Sal}$ monella antigen are shown in fig. 5a for 12 mice vaccinated 35 days previously with $2 \times 10^{8} \mathrm{cfu}$ of $\mathrm{S} 25 / 1$ aro $A$ and for 12 unvaccinated mice. Although all the vaccinated mice produced strong proliferative responses following antigen stimulation which were significantly different from those of the unvaccinated mice, six of the unvaccinated mice showed high responses. These responses in unvaccinated mice were not due to the presence of intestinal flora which crossreacted with Typhimurium, as germ-free BALB/c mice responded in the same way (results not shown). A more likely explanation for these responses is that high levels of LPS in the antigen preparation caused polyclonal stimulation of B cells in certain spleen cell cultures.

All five sheep showed responses to strain S25/1 aro A at all times after vaccination which were significantly greater than before (day 0 ) vaccination (fig. $5 b$ ).

Production of IFN- $\tau$ in response to Salmonella antigen in vitro by spleen cells or PBMC from aroAvaccinated animals

Cells from both mice and sheep were stimulated with antigen 35 days after vaccination. The titres of supernates taken $96 \mathrm{~h}$ after antigen stimulation are shown in table II. Titres of supernates taken 24 and $48 \mathrm{~h}$ after stimulation were very similar and hence are not shown. All 12 vaccinated mice produced IFN- $\tau$ whereas none of the unvaccinated mice did so. None of the vaccinated or unvaccinated sheep produced IFN- $\tau$ following stimulation with Salmonella antigen (results not shown).

\section{Phenotype analysis of $P B M C$ responding to Salmonella antigen in vitro}

The absence of IFN- $\tau$ in Salmonella-stimulated PBMC cultures suggested that LTT responses in sheep 


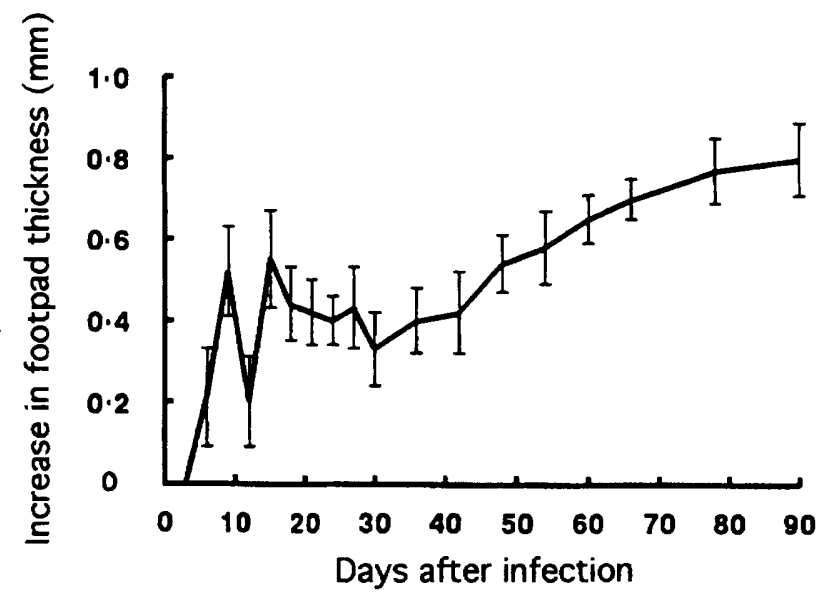

Fig. 4. Specific DTH responses in mice inoculated orally with $5 \times 10^{7} \mathrm{cfu}$ of strain S25/1aroA. The Salmonella-specific increases in footpad thickness were determined at the stated times after infection. Each point represents the mean increases in mm of five mice. Vertical bars indicate SD. Unvaccinated mice produced increases of $0-0.4 \mathrm{~mm}$, highlighting the specificity of the test.

a

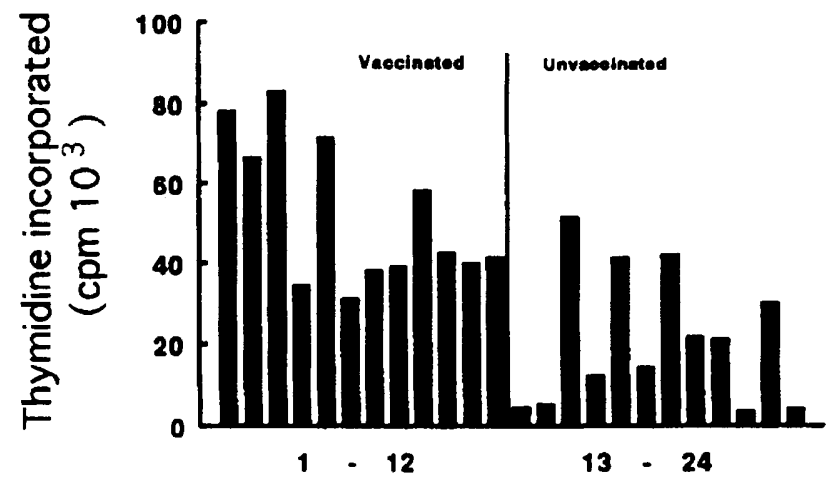

Mouse number

b

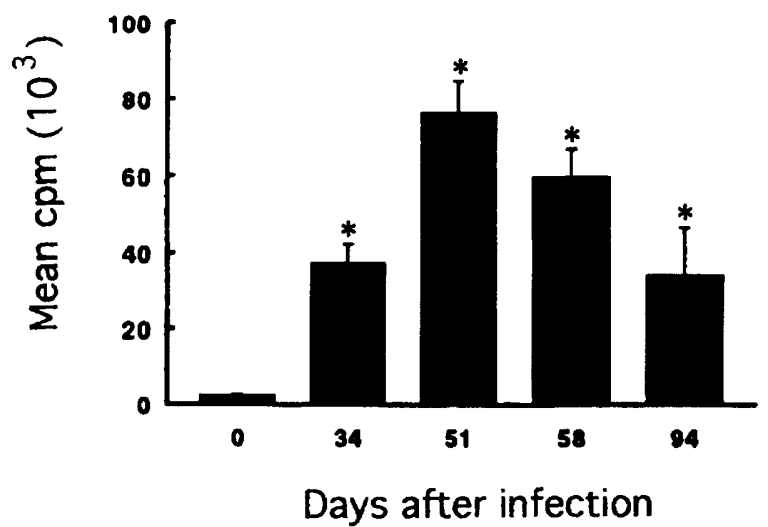

Fig. 5. Specific lymphocyte proliferative responses of mice and sheep after vaccination with strain $\mathrm{S} 25 / 1$ aro $A$. A, mice $1-12$ were vaccinated orally with strain S25/1aroA while mice 13-24 were unvaccinated. The Salmonella antigen-induced LTTs were determined on day 35 after vaccination and the incorporation into thymidine was counted as $\mathrm{cpm}$. B. Five sheep were vaccinated orally with four doses of strain S25/1aroA and the PBMC were cultured with Salmonella antigen before and at various times after vaccination. Mean cpm values for each time-point are shown with standard deviations (vertical bars) ${ }^{*} \mathrm{p}<0.01$.

were not due to T-lymphocyte proliferation. Therefore, the cell-surface phenotype of the responding cells were determined by flow cytometry before and 35 days after vaccination with the $\mathrm{S} 25 / 1$ aro $A$ strain. Before vaccination the proliferative responses in the LTT were low (fig. $5 \mathrm{~b}$ ), and of the responding cells (blast cells), $68 \%$ expressed the immunoglobulin light chain, i.e., were B cells (fig. 6b). After vaccination, there was an increase in the percentage of the total cells that were B cells (from 21 to $50 \%$ ) (fig. 6a) of which $c .90 \%$ were blast cells. There was no increase in either the total number of $\mathrm{CD} 4+, \mathrm{CD} 8+$ or T-cell-receptor $\tau-\delta+$ cells, or in the number of blast cells expressing these molecules following vaccination. Thus, it appears that 


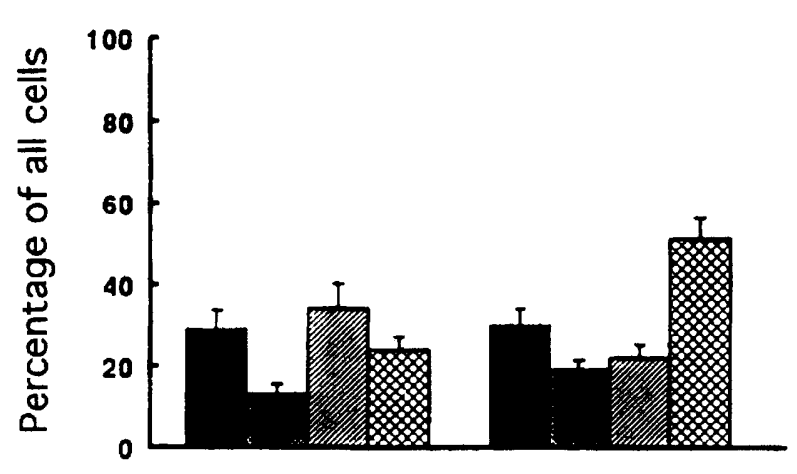

b

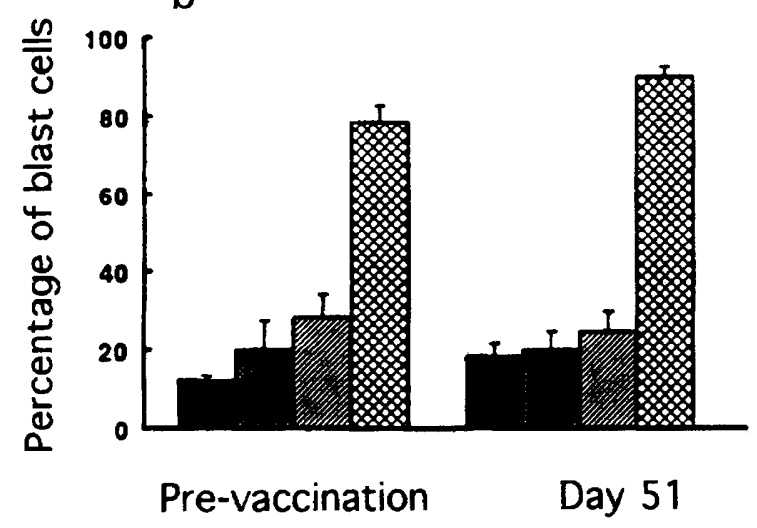

Fig. 6. Phenotype of cells responding to Salmonella antigen in vitro. PBMC from five sheep were stimulated with Salmonella antigen before and 51 days after vaccination with four doses of (5-9) $\times$ $10^{11} \mathrm{cfu}$ of strain S25/1aroA. The mean percentage of both (a) total cells and (b) blast cells that were CD4+ ( $\mathbf{0}), \mathrm{CD} 8+(\mathrm{O})$, T-cell receptor (TcR) $\tau-\delta+($ 溫) and Ig light chain (LC) + (B) were compared at these two time-points.

the responses of PBMC to Salmonella antigen were due to specific $\mathrm{B}$-cell proliferation in the absence of $\mathrm{T}$ cell responses.

Challenge of aroA-vaccinated mice and sheep with wild-type strain $S 25 / 1$

All vaccinated mice were protected from challenge with the virulent strain and showed no clinical signs of
Table II. IFN $-\tau$ production by spleen cells from vaccinated and unvaccinated mice after stimulation with Salmonella antigen in vitro

\begin{tabular}{lrrrrrrrrrrrr}
\hline & \multicolumn{11}{c}{ IFN- $\gamma$ titre in mouse no.* } \\
\cline { 2 - 5 } \\
\cline { 2 - 11 } & 1 & 2 & 3 & 4 & 5 & 6 & 7 & 8 & 9 & 10 & 11 & 12 \\
\hline Vaccinated & 16 & 16 & 16 & 16 & 16 & 8 & 4 & 16 & 16 & 8 & 8 & 8 \\
Unvaccinated & 0 & 0 & $<2$ & 0 & 0 & 0 & 0 & 0 & $<2$ & 0 & 0 & 0
\end{tabular}

* Spleen cells from 12 unvaccinated mice and 12 mice vaccinated 30 days previously with $5 \times 10^{7} \mathrm{cfu}$ of strain $\mathrm{S} 25 /$ laro A were cultured with decreasing doubling dilutions (from $10^{7} \mathrm{cfu} /$ well) of Salmonella antigen for 4 days when the titres of IFN- $\tau$ in the supernates were determined (see Materials and methods).

infection. However, all the unvaccinated mice developed sever clinical signs and succumbed to infection between days 5 and 8 , when the organism was recovered from the spleens, livers and Peyer's patches in high numbers $\left(10^{7}-10^{9} \mathrm{cfu} / \mathrm{g}\right.$ of tissue).

The mean rectal temperatures of both the vaccinated and unvaccinated groups of sheep are shown in fig. 7. After $48 \mathrm{~h}$, pyrexia was observed in all the vaccinated sheep $\left(0 \cdot 7-2 \cdot 4^{\circ} \mathrm{C}\right)$, but they all looked well, retained their appetites and no haemoconcentration was observed. By $72 \mathrm{~h}$ the temperatures had dropped, although pre-vaccination temperatures were not reached until 14 days after challenge. Only one sheep developed diarrhoea (from days 7 to 12) but it remained otherwise clinically well throughout, and all four remaining sheep produced faecal pellets throughout the course of the challenge. The sheep were culled on day 18 after challenge when most of the tissues tested were free of the challenge strain (table III). The aro $A$ vaccine strain could still be recovered from the organs of three of the sheep at this time.

In contrast to the mild clinical responses seen in vaccinated sheep, unvaccinated sheep developed a lethal infection. After $24 \mathrm{~h}$ there was an increase $\left(2 \cdot 3-3 \cdot 0^{\circ} \mathrm{C}\right)$ in rectal temperatures of all the sheep and loss of appetite was observed until termination of the

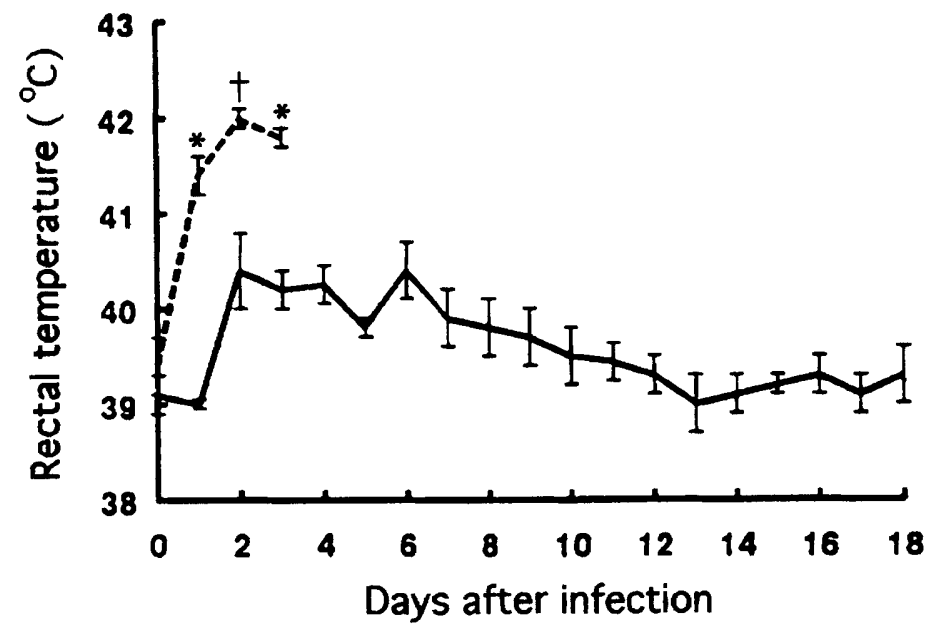

Fig. 7. Rectal temperature responses in vaccinated (-) and unvaccinated (---) sheep after challenge with wild-type strain S25/1. Five sheep vaccinated orally 40 days previously with four doses of $(5-9) \times 10^{11} \mathrm{cfu}$ of strain $\mathrm{S} 25 / 1$ aro $A$, and five unvaccinated sheep were challenged orally with $8 \times 10^{9} \mathrm{cfu}$ of wild-type strain S25/1 and the mean rectal temperatures for the two groups were recorded on each day after challenge; ${ }^{*} \mathrm{p}<0.01, \dagger \mathrm{p}<0.05$. 
Table III. Recovery of the wild-type strain from vaccinated and unvaccinated sheep challenged with wild-type strain $\mathrm{S} 25 / 1$

\begin{tabular}{|c|c|c|c|c|c|c|c|c|c|c|}
\hline \multirow{3}{*}{ Tissue } & \multicolumn{10}{|c|}{ Viable count $(\mathrm{cfu} / \mathrm{g})$ in tissue from } \\
\hline & \multicolumn{5}{|c|}{$\begin{array}{l}\text { Vaccinated } \\
\text { sheep no.* }\end{array}$} & \multicolumn{5}{|c|}{$\begin{array}{l}\text { Unvaccinated } \\
\text { sheep no. }{ }^{*}\end{array}$} \\
\hline & 1 & 2 & 3 & 4 & 5 & 1 & 2 & 3 & 4 & 5 \\
\hline Heart & 0 & 6 & 0 & 0 & 0 & 4 & 0 & $10^{3}$ & 250 & 0 \\
\hline Lung & 0 & 0 & 0 & 0 & 41 & 12 & 437 & 0 & 520 & $10^{3}$ \\
\hline $\mathrm{BLN}$ & 0 & 0 & 0 & 0 & 6 & 0 & 66 & $10^{4}$ & 0 & $10^{3}$ \\
\hline Liver & 0 & 0 & 0 & 0 & 0 & 87 & 19 & $10^{3}$ & 21 & 51 \\
\hline HLN & 0 & 0 & 0 & 0 & 0 & 172 & 28 & 487 & 0 & 294 \\
\hline Spleen & 0 & 0 & 0 & 0 & 0 & 8 & 4 & $10^{5}$ & 50 & 95 \\
\hline Kidney & 0 & 0 & 0 & 0 & 0 & 0 & 0 & $10^{3}$ & 5 & 286 \\
\hline MLN & 0 & 0 & 2 & 4 & 0 & $10^{4}$ & $10^{4}$ & $10^{3}$ & $10^{4}$ & $10^{4}$ \\
\hline Ileum & 0 & 0 & 0 & 0 & 0 & $10^{3}$ & 400 & $10^{6}$ & 153 & 184 \\
\hline Caecum & 0 & 0 & 0 & 15 & 0 & $10^{6}$ & $10^{5}$ & $10^{7}$ & $10^{6}$ & $10^{3}$ \\
\hline Colon & 0 & 0 & 0 & 3 & 0 & $10^{3}$ & $10^{7}$ & $10^{7}$ & $10^{3}$ & $10^{3}$ \\
\hline
\end{tabular}

BLN, bronchial lymph node; HLN, hepatic lymph node; MLN, mesenteric lymph node.

* Five sheep vaccinated 40 days previously with four doses of $10^{11} \mathrm{cfu}$ of strain $\mathrm{S} 25 / 1$ aroA, and five unvaccinated sheep were challenged orally with $8 \times 10^{9} \mathrm{cfu}$ of wild-type strain $\mathrm{S} 25 / 1$. The unvaccinated sheep were culled in extremis on day 3 and the vaccinated sheep were culled on day 18 .

experiment. The mean rectal temperatures of the unvaccinated sheep were significantly higher than those of the vaccinated group on all days tested. There was a significant increase $(\mathrm{p}<0.05)$ in the percentage packed cell volume of the blood, rising from a mean pre-infection level of $36 \cdot 6$ to $44 \cdot 1 \%$. Sheep were culled on day 3 when two of the sheep had developed diarrhoea and all five sheep were clearly in distress. The mesenteric lymph nodes and the intestines of all the sheep contained high numbers of the challenge organism but only in sheep no. 3 were high numbers recovered from other tissues (table III). This may be a result of the early culling of these animals.

\section{Discussion}

In this study, mice infected orally with $1 \times 10^{8} \mathrm{cfu}$ of strain S25/1 aro $A$ showed no clinical signs and did not succumb to infection. BALB/c mice have been shown to tolerate doses of $5 \times 10^{9} \mathrm{cfu}$ of strain $\mathrm{S} 25 / 1$ aro $A$ (J. J. Oliver, unpublished observations). Earlier studies estimated the oral LD50 of the wild-type strain to be $2 \times 10^{2 \cdot 81} \mathrm{cfu}$; hence there is a difference of at least $10^{6} \mathrm{cfu}$ in the minimum oral LD50 of the aro $A$ and wild-type strains of $\mathrm{S} 25 / 1$ in BALB/c mice. The aro $A$ strain colonised the reticulo-endothelial system of both mice and sheep after oral infection and there was longterm persistence of the vaccine strain in vivo, as it was recovered from the mice on day 90 and from the sheep on day 58.

Oral vaccination of mice with a single dose of aro $A$ produced high titres of Salmonella-specific IgM, IgG and $\operatorname{IgA}$ in the serum, and $\operatorname{IgA}$ in the intestine. Titres of serum $\operatorname{IgA}$ antibody reflected those of intestinal $\operatorname{IgA}$, although titres in serum generally appeared 1-2 days later. This suggests that there may be absorption of $\operatorname{IgA}$ produced in the gut into the bloodstream of the mucosa, or simultaneous priming of IgA-producing B cells in the intestine and in the lymph nodes. Such association of serum and gut IgA has not been reported in man following oral vaccination with a live Typhi vaccine $(T y 21 a){ }^{25}$

The strong vaccine-specific humoral responses in mice were in contrast to the much reduced responses in sheep. Salmonella-specific serum IgM was detected in relatively high amounts; however, levels of specific serum IgG were low and specific copro-antibody was absent. These findings are in accordance with those of Lascelles et al. who were unable to detect IgAproducing $\mathrm{B}$ cells in the sheep intestine after repeated oral vaccination with aro $A$ Typhimurium. ${ }^{26}$ They found that primary oral immunisation gave rise to mainly IgM-producing cells. Others have been unable to detect serum antibody after oral vaccination with aro $A$ Typhimurium. ${ }^{15,16}$

Mice produced strong vaccine-specific DTH responses that were still increasing 90 days after infection. DTH testing did not prove effective in demonstrating T-cell immunity in sheep, as all sheep produced strong responses whether or not they had been vaccinated, making the results impossible to interpret. Oral vaccination of sheep with aroA Typhimurium has been shown to be ineffective in eliciting Salmonella-specific DTH responses to the LPS and flagella of the vaccine strain $;{ }^{7,15,16}$ however, the lack of responses to LPS were not surprising as it is a T-cellindependent B-cell mitogen.

To try and detect $\mathrm{T}$-cell responses to the vaccine in sheep, and to further demonstrate T-cell responses in vaccinated mice, the proliferative responses of ovine PBMC and murine spleen cells to Salmonella antigen were examined. Both mice and sheep cells produced strong Salmonella-specific responses after vaccination, but only murine cells produced IFN- $\tau$ in response to antigen stimulation. The lack of IFN- $\tau$ production by PBMC from vaccinated sheep suggested that it was B cells that were responding, or that a population of $\mathrm{T}$ cells that does not produce IFN- $\tau$, such as Th2 cells were responding. Furthermore, phenotype analysis also showed that the responding cells were predominantly B cells and there was no increase in the percentage of $T$ cells after vaccination. This would account for the lack of IFN- $\tau$ in PBMC culture supernates from these sheep, predominance of $\operatorname{IgM}$ in the serum and lack of $\operatorname{IgG}$ and $\operatorname{IgA}$, as these latter responses are $\mathrm{T}$-cell-dependent.

Despite the quite different responses to $\mathrm{S} 25 / 1$ aro $A$ in mice and sheep after oral vaccination, both species were completely protected against a lethal dose of the wild-type strain and only mild clinical responses were seen in vaccinated sheep. Unvaccinated sheep developed a lethal infection and the organism were recovered in high numbers from the gut and systemic tissues compared with the low numbers recovered from vaccinated sheep. 
In conclusion, the results show that strain $\mathrm{S} 25 / 1$ aro $A$ is an effective live vaccine in mice and sheep against experimental salmonellosis, although the immune responses mediating this protection may be quite different in the two species.

\section{References}

1. Wray $\mathrm{C}$. Is salmonellosis still a series problem in veterinary practice? Vet Rec 1985; 116: 485-489.

2. Humphrey TJ, Mead GC, Rowe B. Poultry meat as a source of human salmonellosis in England and Wales. Epidemiological overview. Epidemiol Infect 1988; 100: 175-184.

3. Collins FM, Carter PB. Comparative immunogenicity of heatkilled and living oral Salmonella vaccines. Infect Immun $1972 ; 6: 451-458$.

4. Lindberg AA, Robertsson JA. Salmonella typhimurium infection in calves: cell-mediated and humoral immune reactions before and after challenge with live virulent bacteria in calves given live or inactivated vaccines. Infect Immun 1983; 41 : 751-757.

5. Robertsson JA, Lindberg AA, Hoiseth SK, Stocker BAD. Salmonella typhimurium infection in calves: protection and survival of virulent challenge bacteria after immunization with live or inactivated vaccines. Infect Immun 1983; 41: $742-750$.

6. Smith BP, Reina-Guerra M, Hoiseth SK et al. Aromaticdependent Salmonella typhimurium as modified live vaccines for calves. Am J Vet Res 1984; 45: 59-66.

7. Mukkur TKS, McDowell GH, Stocker BAD, Lascelles AK. Protection against experimental salmonellosis in mice and sheep by immunisation with aromatic-dependent Salmonella typhimurium. J Med Microbiol 1987; 24: 11-19.

8. Levine MM, Kaber JB, Black RE, Clements ML. New knowledge on pathogenesis of bacterial enteric infections as applied to vaccine development. Microbiol Rev 1983; 47: $510-550$.

9. Collins FM. Vaccines and cell-mediated immunity. Bacteriol Rev $1974 ; 38: 371-402$.

10. Hoiseth SK, Stocker BAD. Aromatic-dependent Salmonella typhimurium are non-virulent and effective as live vaccines. Nature 1981; 291 : 238-239.

11. Killar LM, Eisenstein TK. Immunity to Salmonella typhimurium infection in $\mathrm{C} 3 \mathrm{H} / \mathrm{HeJ}$ and $\mathrm{C} 3 \mathrm{H} / \mathrm{HeNCrlBR}$ mice: studies with an aromatic-dependent live $S$. typhimurium strain as a vaccine. Infect Immun 1985; 47: 605-612.

12. Sigwart DF, Stocker BAD, Clements JD. Effect of a purA mutation on the efficacy of Salmonella live-vaccine vectors. Infect Immun 1989; 57: 1858-1861.

13. Cooper GL, Venables LM, Nicholas RAJ, Cullen GA, Hormaeche CE. Vaccination of chickens with chickenderived Salmonella enteriditis phage type 4 aroA live oral salmonella vaccines. Vaccine $1992 ; 10: 247-254$.

14. Smith BP, Reina-Guerra M, Stocker BAD, Hoiseth SK, Johnson E. Aromatic-dependent Salmonella dublin as a
The work described in this paper formed part of a $\mathrm{PhD}$ project, funded by the Scottish Office Agriculture and Fisheries Department (SOAFD). parenteral modified live vaccine for calves. Am J Vet Res 1984; 45 : 2231-2235.

15. Begg AP, Walker KH, Love DN, Mukkur TKS. Evaluation of protection against experimental salmonellosis in sheep immunised with 1 or 2 doses of live aromatic-dependent Salmonella typhimurium. Aust Vet J 1990; 67: 294-298.

16. Mukkur TKS, Walker KH. Development and duration of protection against salmonellosis in mice and sheep immunised with live aromatic-dependent Salmonella typhimurium. Res Vet Sci 1992; 52: 147-153.

17. Kleckner N, Reichardt K, Botstein D. Inversions and deletions of the Salmonella chromosome generated by the translocatable tetracycline resistance element Tn10. J Mol Biol 1979; 127: 89-115.

18. Collee JG et al. (eds). In: Mackie and McCartney's Practical medical microbiology, 13th edn. Edinburgh, Churchill Livingstone 1989: 246.

19. Westphal O, Jann K. Bacterial lipopolysaccharides. Extraction with phenol water and further applications of the procedure. In: Whistler RL (ed) Methods in carbohydrate chemistry, vol 5. New York, Academic Press 1965: 83-91.

20. Lindberg AA, Holme T. Evaluation of some extraction methods for the preparation of bacterial lipopolysaccharides for structural analysis. Acta Pathol Microbiol Scand 1972; Section B 80: 751-759.

21. Engvall E, Perlmann P. Enzyme-linked immunosorbent assay (ELISA) quantitative assay of immunoglobulin $\mathrm{G}$. Immunochemistry $1971 ; 8: 871-874$.

22. Haig DM, Windon R, Blackie W, Brown D, Smith WD Parasite-specific $\mathrm{T}$ cell responses of sheep following live infection with the gastric nematode Haemonchus contortus. Parasite Immunol 1989; 11: 463-477.

23. Kaufmann SHE, Hahn H, Berger R, Kirchner H. Interferongamma production by Listeria monocytogenes-specific $\mathrm{T}$ cells active in cellular antibacterial immunity. Eur $J$ Immunol 1983; 13 : 265-268.

24. Wood PR, Rothel JS, McWaters PGD, Jones SL. Production and characterisation of monoclonal antibodies specific for bovine gamma-interferon. Vet Immunol Immunopath 1985 ; 25: $37-46$.

25. Bartholomeusz RCA, Forrest BD, Labrooy JT et al. The serum polymeric IgA antibody response to typhoid vaccination; its relationship to the intestinal IgA response. Immunology 1990; 69: 190-194.

26. Lascelles AK, Beh KJ, Mukkur TKS, Willis G. Immune response of sheep to oral and subcutaneous administration of live aromatic-dependent mutant of Salmonella typhimurium (SL 1479). Vet Immunol Immunopathol 1988; 18 : 259-267. 